Hansell, A., Ghosh, R.E., Poole, S., Zock, J.P., Weatherall, M., Vermeulen, R., Kromhout, H., Travers, J., Beasley, R. Occupational risk factors for chronic respiratory disease in a New Zealand population using lifetime occupational history. Journal of Occupational and Environmental Medicine: 2014, 56(3), 270-280

\begin{tabular}{|l|l|}
\hline $\begin{array}{l}\text { Postprint } \\
\text { Version }\end{array}$ & 1.0 \\
\hline Journal website & $\underline{\text { http:///journals.Iww.com/joem/pages/articleviewer.aspx?year=2014\&issue=03000 }}$ \\
\hline \&article=00006\&type=abstract \\
\hline Pubmed link & $\underline{\text { http://www.ncbi.n/m.nih.gov/pubmed/24327054 }}$ \\
\hline DOI & $10.1097 / 01 . j o m .0000438382 .33221 . d c$ \\
\hline
\end{tabular}

This is a NIVEL certified Post Print, more info at http://www.nivel.eu

\title{
Occupational Risk Factors for Chronic Respiratory Disease in a New Zealand Population Using Lifetime Occupational History
}

\author{
Hansell, Anna MB, BChir, PhD; Ghosh, Rebecca E. PhD; Poole, SuZAnne MBChB, \\ MD; ZOCK, JAN-PAUL PHD; WEATHERALL, MARK MBCHB, BA, MAPPLSTATS; \\ Vermeulen, Roel PhD; Kromhout, HaNs PhD; TraVers, Justin MBChB; BeAsley, \\ RICHARD MBCHB, DSC
}

From the MRC-PHE Centre for Environment and Health (Drs Hansell and Ghosh), Imperial College London, London, the United Kingdom; Imperial College Healthcare NHS Trust (Dr Hansell), London, the United Kingdom; Tauranga Hospital (Dr Poole), Tauranga, New Zealand; Centre for Research in Environmental Epidemiology (CREAL) (Dr Zock), Barcelona, Spain; Hospital del Mar Medical Research Institute (IMIM) (Dr Zock), Barcelona, Spain; CIBER Epidemiología y Salud Pública (CIBERESP) (Dr Zock), Spain; University of Otago Wellington (Prof Weatherall), Wellington, New Zealand; Institute for Risk Assessment Sciences (Profs Vermeulen and Kromhout), Utrecht University, Utrecht, The Netherlands; Medical Research Institute of New Zealand (Dr Travers), Wellington, New Zealand; and University of Otago, North Dunedin, New Zealand (Prof Beasley).

Address correspondence to Anna Hansell, MB, BChir, PhD, MRC-PHE Centre for Environment and Health, Department Epidemiology and Biostatistics, Imperial College London, Norfolk Place, London W2 1PG, the United Kingdom (a.hansell@imperial.ac.uk). The Wellington Respiratory Survey was supported by a research grant from GlaxoSmith Kline. A.H. was funded by Wellcome Trust (grant 075833).

The authors have no conflicts of interest to report.

Supplemental digital content is available for this article. Direct URL citations appear in the printed text and are provided in the HTML and PDF versions of this article on the journal's Web site (www.joem.org).

\begin{abstract}
Objectives: To investigate associations between respiratory disease and occupational exposures in a New Zealand urban population, the Wellington Respiratory Survey.

Methods: Multiple regression analyses in a population sample of 1017 individuals aged 25 to 74 years with spirometry and questionnaire information, including a lifetime occupational history.

Results: Chronic bronchitis symptoms were associated with self-reported exposure to hairdressing, paint manufacturing, insecticides, welding, detergents and with ALOHA Job Exposure Matrix-assessed gases/fumes exposure. The
\end{abstract}


Hansell, A., Ghosh, R.E., Poole, S., Zock, J.P., Weatherall, M., Vermeulen, R., Kromhout, H., Travers, J., Beasley, R. Occupational risk factors for chronic respiratory disease in a New Zealand population using lifetime occupational history. Journal of Occupational and Environmental Medicine: 2014, 56(3), 270-280

strongest association was for hairdressing (odds ratio 6.91; 95\% confidence interval: 2.02 to 23.70). Cumulative exposure to mineral dust and gases/fumes was associated with higher $\mathrm{FEV}_{1} \%$ (forced expiratory volume in the first second of expiration) predicted. Analyses were limited by relatively small numbers of cases.

Conclusions: Increased risks of objectively defined respiratory disease, which have been previously documented, were not seen. Nevertheless, the study suggested increased risk of respiratory symptoms with various occupational exposures as well as likely healthy worker effect.

Chronic obstructive pulmonary disease (COPD) is a major cause of mortality and morbidity, accounting for more than $6 \%$ of all deaths in New Zealand in $2009 .{ }^{1}$ While the majority of COPD cases are caused by smoking, occupational contributions are important ${ }^{2-4}$ with a suggested 15\% of COPD cases attributable to occupational exposures. ${ }^{5,6}$ Among never smokers, the population attributable risk for occupation may be as high as $40 \%{ }^{\cdot 7}$ Well-established occupational causes of COPD include exposure to coal dust and working in industries with long-term exposure to fumes, chemical substances, and organic dusts. ${ }^{4}$ A previous New Zealand study published in $1997^{8}$ identified increased risks of COPD for specific occupational groups including bakers, other food processors, spray painters, hairdressers, and nurses.

This study investigated the relationship between occupations, occupational exposures, and COPD defined by symptoms and self-reported doctor diagnosis and spirometry in a New Zealand population, where a lifetime occupational history was available.

\section{METHODS}

\section{Study Population}

The analyses were conducted using the Wellington Respiratory Survey, a two-stage survey conducted in 2003 to 2004 . $^{9}$ An age-stratified randomly selected sample of 3500 people on the electoral roll in Wellington, New Zealand (2.5\% of the eligible population), were selected, of whom 2978 had valid contact details and 2319 returned a screening questionnaire. Of these, 1017 (43.9\% of the 2319 and 34.2\% of the original 2978) went on to complete a more detailed questionnaire on respiratory symptoms, diagnosed disease and medication, occupational exposures, and lifetime occupational history, and were additionally invited for respiratory function testing including pre- and postbronchodilator spirometry.

\section{Occupational Exposures}

Occupational exposure was assessed via:

1. Self-reported exposure to 1 of 18 specific occupational exposures or work circumstances considered a priori risk factors for COPD or asthma (see Appendix 1 for list and details, available at http://links.lww.com/JOM/A136)—answer yes to the question "Have you 
Hansell, A., Ghosh, R.E., Poole, S., Zock, J.P., Weatherall, M., Vermeulen, R., Kromhout, H., Travers, J., Beasley, R. Occupational risk factors for chronic respiratory disease in a New Zealand population using lifetime occupational history. Journal of Occupational and Environmental Medicine: 2014, 56(3), 270-280

worked in business/industry where you have been exposed to.” The reference group was those who reported never having any exposure.

2. The ALOHA job exposure matrix (JEM), a community-based JEM, was originally developed for the European Respiratory Health Survey. ${ }^{10}$ This JEM estimates exposure for those working in jobs with ever a high or only ever low exposure to biological dust, mineral dust, and gas/fumes or any vapors, gases, dusts, or fumes (VGDF), taking into account both intensity and prevalence of exposure. In addition, the JEM was used to define a semiquantitative estimate of cumulative exposure (years) by multiplying the duration of a job with an assigned intensity (high exposure $=4$, and low exposure $=1)^{11}$ accumulated over the full occupational history. This was used to create categories (tertiles) of cumulative exposure (excluding individuals without exposure). The comparison group for each analysis using the ALOHA JEM was those who had never reported working in any job with any VGDF exposures (ie, a clean, never-exposed comparison group was used).

The ALOHA JEM was linked to a full occupational history in the form of free text information on place of work, position, and start and finish year. The text was coded by Statistics New Zealand (SNZ) to the New Zealand Standard Classification of Occupations 1999 (NZSCO-99) ${ }^{12}$ coding system (an adapted version of the International Standard Classification of Occupations 1988, ISCO-88) using a computer program with additional hand-checking at SNZ. Subsequently, job titles of all jobs coded to 97000 (response unidentifiable) and 99000 (response outside scope) were hand-checked including cross-checking against original questionnaires where necessary to see if these could be coded (by A.H.). NZSCO-99 codes were then back-mapped to ISCO-88 by SNZ to permit the use of the ALOHA JEM. Handchecking of 475 one-to-many mappings was conducted (by A.H. with advice from J.P.Z.). Queries were cross-checked with the original questionnaires where necessary and cleaning was also conducted with respect to start and finish years (eg, finish year before start year, years not compatible with age).

\section{OUTCOMES}

used:

The following four obstructive airways disease-related outcomes were

1. COPD defined as the postbronchodilator $\mathrm{FEV}_{1} / \mathrm{FVC}$ (forced expiratory volume in the first second of expiration/forced vital capacity) ratio below the lower fifth percentile of a healthy reference population (the statistically defined lower limit of normal [LLN]) in the absence of another lung disease ${ }^{9}$ (see Appendix 2 for the reference equation, available at http://links.lww.com/JOM/A136).

2. Chronic bronchitis symptoms defined as self-reported cough and sputum for as many as 3 months each year (see Appendix 2 for questions, available at http://links.lww.com/JOM/A136).

3. Self-reported doctor diagnosis of COPD, chronic bronchitis, or emphysema (see Appendix 2 for questions, available at http://links.lww.com/JOM/A136). 
Hansell, A., Ghosh, R.E., Poole, S., Zock, J.P., Weatherall, M., Vermeulen, R., Kromhout, H., Travers, J., Beasley, R. Occupational risk factors for chronic respiratory disease in a New Zealand population using lifetime occupational history. Journal of Occupational and Environmental Medicine: 2014, 56(3), 270-280

4. Predicted $\mathrm{FEV}_{1}$ percentage from tests of asymptomatic nonsmokers in the NHANES III study ${ }^{13}$ (see Appendix 2 for the reference equation, available at http://links.lww.com/JOM/A136).

\section{ANALYSES}

Statistical analyses were conducted using Stata version $11 .{ }^{14}$ Logistic regression was used to examine associations between occupational exposures and the categorical outcomes, while linear regression was used to examine the predicted $\mathrm{FEV}_{1} \%$ as a continuous outcome. Adjustments were made for sex, age, age-squared, smoking, ethnicity, and deprivation of area, except for $\mathrm{FEV}_{1}$ analyses where the age-squared term was not used (since reference equations were derived from an external reference population [NHANES III] ${ }^{13}$ using nonsmokers without respiratory disease). Participants had good predictive value without this term. ${ }^{15}$ We controlled for both age and age squared because there was a weak negative association between the age at starting first job and age $\mathrm{e}^{2}=-0.237 ; \mathrm{P}<0.001$ ) and regression analysis suggested an average year earlier starting work for every 16 years increase in age (data not shown), which could have resulted in longer duration to higher exposures in earlier years in older individuals. The smoking variable used was pack years, where one pack year is equivalent to smoking 20 cigarettes per day for 1 year, or equivalent tobacco consumption for roll-up cigarettes. Ethnicity was defined as "New Zealand Caucasian," "Maori or Pacific Islander," and “other or mixed.” The deprivation measure used was the NZDep2001 index, which provides average deprivation of a mesh block - a geographical unit defined by SNZ containing a median of 90 people. ${ }^{16}$ The index is a principal component score derived from the average proportion of people in the mesh block in each of nine Census variable categories using 2001 Census data, which is then converted into an ordinal 10-point scale relating to tenths of the distribution across New Zealand as a whole, where 1 represents the least deprived area and 10 the most deprived.

As several outcomes and different ways of characterizing exposure were explored, we used different methods to assess the impact of multiple testing (we also note that analyses are not completely agnostic and for some there is considerable prior evidence). The Simes procedure was used to generate q-values by inverting multipletest procedures using the "q-value" package in STATA ${ }^{17}$; the q-value corresponds to the minimum false detection rate at which the test may be called significant $(\mathrm{P}<$ 0.05 ), so for associations with a q-value $<0.05$ we can be $90 \%$ confident that these are not due to chance. Consistency in analyses across different outcomes was also considered. Only results with at least five cases are reported. ${ }^{18}$

\section{RESULTS}

\section{Description of Participants and Exposures}

There were 1017 individuals with completed questionnaires and 750 with both questionnaire and valid postbronchodilator and forced vital capacity lung function data (Table 1). Nearly a quarter of all participants had ever had asthma diagnosed 
Hansell, A., Ghosh, R.E., Poole, S., Zock, J.P., Weatherall, M., Vermeulen, R., Kromhout, H., Travers, J., Beasley, R. Occupational risk factors for chronic respiratory disease in a New Zealand population using lifetime occupational history. Journal of Occupational and Environmental Medicine: 2014, 56(3), 270-280

(23.9\%). The prevalence of the four main outcomes ranged from 9\% for chronic bronchitis symptoms to $11 \%$ for doctor diagnosis and COPD LLN. There was generally a $20 \%$ to $30 \%$ overlap for most main outcomes combinations (Table A1 in Appendix 3 in online supplement, available at http://links.lww.com/JOM/A136). Men were disproportionately represented in those with an $\mathrm{FEV}_{1} / \mathrm{FVC}$ ratio below the LLN (14\% in men vs $8 \%$ in women) but fewer men than women reported a doctor diagnosis of COPD, emphysema, or chronic bronchitis (9\% vs 13\%). There was less deprivation compared to the New Zealand population as a whole with only a quarter living in areas in the bottom half of the NZDep2001 scores. Men reported occupational exposures more frequently than women, with the three most frequently reported exposures in men being solvents (40\%), wood dust (32\%), and soldering (21\%) and in women solvents (18\%), detergents (16\%), and pigments (8\%) (Table 2).

\section{[TABLE 1][TABLE 2]}

Occupational exposures were assigned by applying the ALOHA JEM to the occupational histories for 1014 individuals. Overall, 55\% of the survey participants had ever worked in a job with VGDF as assessed by the JEM (Table 2), but this was higher in men (62\%) than in women (49\%). Men were more likely to have had jobs with exposure to mineral dusts and gas or fumes, but around $40 \%$ of either sex had had a job with exposure to biological dusts. Approximately 1000 persons gave information about both occupation and commencement/cessation dates allowing calculation of cumulative exposure for different exposures. A small number of individuals had more than 50 years of working life in a job assessed by the JEM to be high risk, which was by design weighted by a factor of 4 , so some of the weighted cumulative exposure years were greater than 200 (Table 3).

\section{[TABLE 3]}

\section{SELF-REPORTED EXPOSURES}

Analyses were limited by small numbers reporting some exposures/work circumstances. An increased risk of chronic bronchitis symptoms was seen with selfreported exposure to detergents (odds ratio [OR] 2.16; 95\% CI 1.13 to 4.09; q = 0.153), paint manufacturing (OR 3.46; 95\% CI 1.09 to 11.05; $q=0.153$ ), insecticides (OR 2.35; 95\% CI 1.05 to 5.26; q = 0.153), welding (OR 2.27; 95\% CI 1.02 to 5.08; $\mathrm{q}=0.153$ ), and hairdressing (OR 6.91; 95\% CI 2.02 to $23.70 ; \mathrm{q}=$ 0.034 ) but, taking multiple testing into account, only hairdressing had a significant q-value, as indicated by q $<0.05$ (Table 4). Reported exposure to solvents, detergents, and asbestos were associated with higher $\mathrm{FEV}_{1} \%$ predicted of approximately 3\% to 5\%, although none of these associations had significant qvalues. 
Hansell, A., Ghosh, R.E., Poole, S., Zock, J.P., Weatherall, M., Vermeulen, R., Kromhout, H., Travers, J., Beasley, R. Occupational risk factors for chronic respiratory disease in a New Zealand population using lifetime occupational history. Journal of Occupational and Environmental Medicine: 2014, 56(3), 270-280

\section{[TABLE 4]}

\section{ALOHA JEM EXPOSURES}

Increased risks of chronic bronchitis symptoms that reached conventional (but not multiple-testing adjusted) statistical significance were seen (Table 5) with Table 5.

\section{[TABLE 5]}

1. Only ever low mineral dust exposures (OR 2.04; 95\% CI: 1.06 to 3.93).

2. Ever high gas or fumes exposure (OR 2.10; 95\% CI: 1.11 to 3.98). High mineral dust exposure was also associated with a 4.37\% higher $\mathrm{FEV}_{1} \%$ predicted after adjustment (95\% CI: 0.30 to 8.46; $q=0.070$ ) than those not exposed, but this was not significant after correction for multiple testing. A 5.83\% higher $\mathrm{FEV}_{1} \%$ predicted was also seen for those ever exposed to high gases or fumes (95\% CI: 1.94 to $9.71 ; \mathrm{q}=0.024)$, a $4.38 \%$ higher $\mathrm{FEV}_{1} \%$ predicted ever high any VGDF exposure (95\% CI: 0.92 to 7.83; $\mathrm{q}=0.035$ ), and a 3.96\% higher $\mathrm{FEV}_{1} \%$ predicted ever having had low exposure to biological dust (95\% CI: 0.85 to 7.06 ; $q=0.035$ ), all of which remained significant after correction for multiple testing (Table 5).

As a lifetime occupational history was collected, it was possible to estimate weighted cumulative exposure years (Table 3). No associations with cumulative exposure were seen with COPD LLN, doctor-diagnosed COPD or chronic bronchitis symptoms. A significantly higher $\mathrm{FEV}_{1} \%$ predicted was seen in the longest exposed JEM category for mineral dust (29.5 to 188 years-6.62\% higher; $95 \%$ CI: 1.80 to 11.44 ; q = 0.042 ) and the longest exposed JEM category for gases or fumes (28.5 to 192 years-6.21\% higher; 95\% CI 2.32 to 10.09 ; $q=0.024)$. These were significant after correction for multiple testing. The middle category of exposure to biological dust was significantly associated with a higher $\mathrm{FEV}_{1} \%$ predicted ( 7 to 26 years- $4.48 \%$ higher; 95\% CI: 0.35 to 8.62; q = 0.117), but not after adjustment for multiple testing.

\section{DISCUSSION}

This New Zealand population-based study used a lifetime occupational history to examine occupational risks for four different measures of chronic obstructive respiratory disease, using lifetime occupational histories and self-reported occupational exposures. The main limitations of this study are the relatively small numbers in some of the occupational groups reducing our power to detect associations. The large age range of our population also meant that we had fewer individuals in the older age groups (less than $50 \%$ were older than 55 years) and COPD does not usually present until late middle age or old age. ${ }^{20}$ In addition, there was possible bias from selection and reporting, the healthy worker effect, and job selection as well as possible error from multiple comparisons. Approximately a quarter of the New Zealand population is currently exposed to dust and gases or fumes in the workplace ${ }^{21}$ and the present study found that $55 \%$ had ever been exposed (Table 2). The most consistent associations were seen with selfreported chronic bronchitis symptoms. Self-reported exposure to hairdressing, paint manufacturing, insecticides, welding, and detergents were all associated with an 
Hansell, A., Ghosh, R.E., Poole, S., Zock, J.P., Weatherall, M., Vermeulen, R., Kromhout, H., Travers, J., Beasley, R. Occupational risk factors for chronic respiratory disease in a New Zealand population using lifetime occupational history. Journal of Occupational and Environmental Medicine: 2014, 56(3), 270-280

increased risk of chronic bronchitis symptoms, with the highest ORs seen for hairdressing. Chronic bronchitis symptoms were also associated with low mineral dust exposure and high gases or fumes exposure assessed using the ALOHA JEM.

An increase in the $\mathrm{FEV}_{1} \%$ predicted (adjusted for confounders including age, height, and sex) was associated with self-reported exposure to detergents, solvents, and asbestos. Increased $\mathrm{FEV}_{1} \%$ predicted was also found in analyses of ever exposure (Table 5) in individuals with low biological dust exposure, high mineral dust, and high gases and fumes exposure. Increased $\mathrm{FEV}_{1} \%$ predicted was also seen with the middle category of cumulative exposure to biological dust (Table 3), high cumulative mineral dust exposure, and high cumulative gases and fumes exposure. This likely represents a healthy worker effect, as the significantly increased $\mathrm{FEV}_{1} \%$ predicted was generally seen in those with the longest exposures, that is, the group most likely to contain healthy survivors.

The associations seen between self-reported chronic bronchitis symptoms and selfreported exposures have been documented in other studies, including in New Zealand. Hairdressers are exposed to a wide range of chemicals and irritants ${ }^{22}$ and associations with other respiratory conditions such as occupational asthma are well recognized. ${ }^{22}$ There were 11 people who had ever had a hairdressing job (based on the occupational history), but 19 individuals had reported a hairdressing exposure. This discrepancy may be due to the occupational history questionnaire, which included jobs that had lasted more than 6 months while the self-reported exposure asked if the participant had ever worked in hairdressing. An earlier New Zealand study by Fishwick et al ${ }^{8}$ found that hairdressers had an increased risk of shortness of breath. A subsequent New Zealand study did not find an excess of chronic bronchitis symptoms in hairdressers currently working in salons. ${ }^{23}$ Nevertheless, we considered ever exposed and as such, it may be that our observed associations are related to exposures that occurred further in the past and represent a healthy worker effect or changes in hairdressing products over time.

Other studies have also shown increased risks of chronic bronchitis in cleaners, ${ }^{8,24}$ which is consistent with self-reported exposure to detergents. In addition, associations of chronic bronchitis with welding have been found in previous studies ${ }^{25}$ including at New Zealand welding sites. ${ }^{26,27}$ Spray painters have also previously been shown to be at a greater risk of chronic bronchitis and mild airway obstruction. ${ }^{8}$

Other occupations that have previously been identified as being associated with an increased risk of developing COPD include farming (particularly animal or grain), flourmill worker and bakers, textile work, and welding. ${ }^{4}$ New Zealand studies of specific occupational groups have also identified agricultural workers as at increased risk of respiratory diseases. ${ }^{28}$ Self-reported insecticide exposure was associated with an increased risk of reporting chronic bronchitis symptoms and this exposure is most likely to occur in farming occupations. A previous study of New Zealand agricultural workers found that $4.5 \%$ of the New Zealand population was agricultural workers and that $60 \%$ of them reported pesticide exposure. ${ }^{21}$ In the present study, just less than $50 \%$ of those in farming occupations also reported insecticide exposure. Several of the associations identified are with occupations known to be associated with asthma, for example, hairdressing ${ }^{22}$ and cleaning. ${ }^{29}$ Previous work on this New Zealand population has shown close relationships between asthma and COPD. A 
Hansell, A., Ghosh, R.E., Poole, S., Zock, J.P., Weatherall, M., Vermeulen, R., Kromhout, H., Travers, J., Beasley, R. Occupational risk factors for chronic respiratory disease in a New Zealand population using lifetime occupational history. Journal of Occupational and Environmental Medicine: 2014, 56(3), 270-280

diagnosis of childhood asthma was found to increase the risk of developing GOLD COPD (the Global Initiative for Chronic Obstructive Lung Disease [GOLD] criteria for COPD_defined using GOLD criteria for COPD—FEV $/$ FVC ratio $<0.7$ ) and was equivalent to the risk from a 22-year increase in age or 62 pack years of cigarette smoking. ${ }^{30}$ The respondents reported a high lifetime prevalence of asthma (24\%) and analyses showed an overlap between COPD and asthma phenotypes, with the most common presentation being a mixture of both. ${ }^{31}$ Therefore, it is possible that some observed associations in the present study may be related to asthma rather than COPD. Also, people with asthma may be more susceptible to further respiratory effects of occupational exposures ${ }^{32}$ and be more likely to report cough and phlegm symptoms, traditionally associated with COPD. The high prevalence of asthma in this population may also result in greater awareness of respiratory conditions and therefore greater likelihood of both reporting respiratory symptoms and of reporting exposures ${ }^{33}$ if they have symptoms or have had asthma in the past. Conversely, as New Zealand has high rates of childhood asthma, ${ }^{34}$ it is also possible that bias due to job selection is present in this study in that those with prior respiratory disease may avoid work in highly exposed jobs and enter low-risk occupations instead, thereby increasing the prevalence of respiratory symptoms in the reference group ${ }^{35}$ although against this we note that the prevalence of JEM-based exposures in this study did not seem to differ from other studies. ${ }^{36-38}$ We attempted a sensitivity analysis (data not presented) excluding all those with asthma from our analyses but the number of individuals in each group was too small for a clear conclusion to be reached. Furthermore, it is difficult to comment on potential causation or susceptibility related to asthma, given the cross-sectional design of this study. All significant associations with the $\mathrm{FEV}_{1} \%$ predicted showed a higher $\mathrm{FEV}_{1} \%$ predicted as compared to unexposed individuals; in general, this was significant in those with high JEM exposure. When cumulative exposure in years was considered significant, associations seen showed higher $\mathrm{FEV}_{1} \%$ predicted in the longest exposed groups - suggesting that these are healthier survivors. A likely explanation is that due to the cross-sectional nature of this study there is a healthy worker or healthy survivor bias present, that is, that individuals with poorer lung function did not work in these higher-risk occupations. ${ }^{39}, 40$ This may be due to people with COPD leaving jobs that cause or aggravate their symptoms or may be due to job selection. ${ }^{35}$ A further unexpected finding was that few associations were seen with doctordiagnosed COPD. This is not consistent with population sample studies of similar or larger size. ${ }^{8,36},{ }^{41}$ Nevertheless, in two of these, ${ }^{8,41}$ the population samples were enriched with individuals with COPD or respiratory symptoms. This was a general population survey and as such contained many younger individuals who were unlikely to have yet developed COPD. It is also known that older individuals with respiratory symptoms are more likely to be diagnosed with COPD and be underdiagnosed with asthma. ${ }^{42}$ This may, in part, explain why associations seen have been occupational exposures and chronic bronchitis symptoms were not seen in the doctor-diagnosed analyses. A 2005 study of a nonenriched random population sample from Australia ${ }^{38}$ reported associations between COPD (defined as either airflow obstruction with chronic sputum production, airflow obstruction with shortness of breath or GOLD COPD) and biological dust that we were unable to replicate using similar definitions of COPD (Appendix 3, Table A2, available at http://links.lww.com/JOM/A136). A previous New Zealand population study ${ }^{8}$ used 
Hansell, A., Ghosh, R.E., Poole, S., Zock, J.P., Weatherall, M., Vermeulen, R., Kromhout, H., Travers, J., Beasley, R. Occupational risk factors for chronic respiratory disease in a New Zealand population using lifetime occupational history. Journal of Occupational and Environmental Medicine: 2014, 56(3), 270-280

current/most recent occupation to define exposure and showed that exposure to VGDF was a risk factor for the development of respiratory disease including respiratory symptoms, but did not present results for dusts and gases/fumes separately.

Generally, there were few differences between those who completed the main study questionnaire and those completing lung function measurements. ${ }^{9}$ Nevertheless, individuals responding to the main questionnaire were more likely to have reported breathing problems (35\% vs $25 \%$ ) and were more likely to be ex-smokers (42\% vs $36.1 \%$ ), though not current smokers (both 12\%), than those who completed the initial screening questionnaire. This might have introduced bias if such individuals also reported occupational histories or occupational exposures differently. Nevertheless, the occupational history was not collected with specific reference to the individual's health status, which will have reduced the potential for reporting bias in this study. ${ }^{43}$ In addition, associations with chronic bronchitis were seen with both self-reported exposures and the objectively assessed JEM-based exposures in the present study. Furthermore, the ALOHA JEM was linked to the occupational histories blinded to an individual's disease status to minimize the possibility of misclassification bias-any errors relating to the ALOHA JEM are likely to be random and therefore most likely to produce bias toward the null.

This study was located in Wellington, which is the capital city and had relatively small numbers of people in occupations such as heavy industry, farming, and mining, which have been associated in previous studies with chronic respiratory disease. There was less deprivation in this population as compared with the New Zealand population as a whole with only a quarter living in areas in the bottom half of the national NZDep2001 scores. This selection bias may have resulted in individuals with higher occupational exposures being underrepresented in this study population, leading to an underrepresentation of the risk. Despite this, the prevalence of JEMbased exposures in this population was not very different from those in the European Respiratory Health Survey ${ }^{37}$ and the Matheson study ${ }^{38}$ in Australia (which also used lifetime occupational history), suggesting that location did not influence the proportions of people in JEM-exposed occupations.

Another factor to consider is age, which, to some extent, may act as a surrogate for exposure. First, occupational exposures tend to have decreased over time. Second, we observed a negative association between age at survey and the age at starting first job with $r^{2}=-0.24(P<0.001)$. A regression analysis (not shown) suggested an average year earlier starting work for every 16 years increase in age. These factors could have resulted in longer duration of higher exposures in older individuals. Therefore, adjustments for age may have resulted in overadjustment for exposure.

\section{CONCLUSION}

In this population-based study, we found evidence suggestive of a healthy worker effect, but no significant associations with objective measures of lung function or COPD. Nevertheless, individuals were more likely to report chronic bronchitis symptoms if they had worked as a hairdresser, in paint manufacturing, in welding, if exposed to detergents or insecticides, or had reported jobs with exposure to mineral dusts and gases or fumes. Chronic bronchitis symptoms are important because they indicate a group at risk of developing COPD independent of smoking habits and lung 
Hansell, A., Ghosh, R.E., Poole, S., Zock, J.P., Weatherall, M., Vermeulen, R., Kromhout, H., Travers, J., Beasley, R. Occupational risk factors for chronic respiratory disease in a New Zealand population using lifetime occupational history. Journal of Occupational and Environmental Medicine: 2014, 56(3), 270-280

function at baseline. ${ }^{19}$ They are associated with future risk of both overall and COPD mortality ${ }^{44}$ as well as impaired quality of life, independent of COPD or asthma diagnosis. ${ }^{45}$ Increased risks of objectively defined respiratory disease were not seen, but analyses were limited by the cross-sectional nature of the study, limited numbers, and the likely healthy worker bias.

\section{ACKNOWLEDGMENTS}

We thank Joan Soriano for his helpful comments in the design of the Wellington Respiratory Survey; Avrille Holt, Patricia Heuser, and Eleanore Chambers for their help in conducting the questionnaires; Mathew Williams for his help in conducting the pulmonary function tests; Statistics New Zealand for assistance with occupational coding; Roger Newson and Philip Guangquan for advice on multiple testing corrections; and Lesley Rushton and Elizabeth Esan for discussions on occupational analyses at initial stages.

\section{REFERENCES}

1. Ministry of Health. Mortality and Demographic Data 2009. Wellington, New Zealand: Ministry of Health-New Zealand; 2012.

2. Martin P, Glasgow H, Patterson J. Chronic obstructive pulmonary disease (COPD): smoking remains the most important cause. J New Zeal Med Assoc. 2005;118:U1409.

3. Becklake MR. Occupational exposures: evidence for a causal association with chronic obstructive pulmonary disease. Am Rev Respir Dis. 1989;140:S85-S91.

4. Rushton L. Occupational causes of chronic obstructive pulmonary disease. Rev Environ Health. 2007;22:195-212.

5. Blanc PD, Toren K. Occupation in chronic obstructive pulmonary disease and chronic bronchitis: an update. Int J Tuberc Lung Dis. 2007;11:251-257.

6. Balmes J, Becklake M, Blanc P, et al. American Thoracic Society statement: occupational contribution to the burden of airway disease. Am J Respir Crit Care Med. 2003;167:787797.

7. Blanc PD. Occupation and COPD: a brief review. J Asthma. 2012;49:2-4.

8. Fishwick D, Bradshaw L, D'Souza W, et al. Chronic bronchitis, shortness of breath, and airway obstruction by occupation in New Zealand. Am J Respir Crit Care Med. 1997;156:1440-1446.

9. Shirtcliffe $\mathrm{P}$, Weatherall $\mathrm{M}$, Marsh $\mathrm{S}$, et al. COPD prevalence in a random population survey: a matter of definition. Eur Respir J. 2007;30:232-239.

10. Sunyer J, Kogevinas $\mathrm{M}$, Kromhout $\mathrm{H}$, et al. Pulmonary ventilatory defects and occupational exposures in a population-based study in Spain. Am J Respir Crit Care Med. 1998;157:512-517.

11. Stewart PA, Herrick RF. Issues in performing retrospective exposure assessment. Appl Occup Environ Hyg. 1991;6:421-427.

12. Statistics New Zealand. New Zealand Standard Classification of Occupations 1999. Wellington, New Zealand: Statistics New Zealand; 2001.

13. Hankinson JL, Odencrantz JR, Fedan KB. Spirometric reference values from a sample of the general US population. Am J Respir Crit Care Med. 1999;159:179-187.

14. StataCorp. Stata Statistical Software: Release 11. College Station, TX: StataCorp LP; 2009.

15. Marsh S, Aldington S, Williams $M$, et al. Complete reference ranges for pulmonary function tests from a single New Zealand population. N Z Med J. 2006;119:1-16.

16. Howden-Chapman P, Tobias M. Social Inequalities in Health: New Zealand 1999. Wellington, New Zealand: New Zealand Ministry of Health; 2000.

17. Newson RB. Frequentist q-values for multiple-test procedures. Stata J. 2010;10:568584. 
Hansell, A., Ghosh, R.E., Poole, S., Zock, J.P., Weatherall, M., Vermeulen, R., Kromhout, H., Travers, J., Beasley, R. Occupational risk factors for chronic respiratory disease in a New Zealand population using lifetime occupational history. Journal of Occupational and Environmental Medicine: 2014, 56(3), 270-280

18. Benjamini $Y$, Yekutieli D. The control of the false discovery rate in multiple testing under dependency. Ann Stat. 2001;29:1165-1188.

19. Quanjer P, Trammeling G, Cotes J, Pedersen O, Peslin R, Yernault J Lung volumes and forced ventilatory flows. Report of the working party for standardisation of lung function tests. European Community for Steel and Coal. Official statement of the European Respiratory Society. Eur Respir J Suppl. 1993;16:5-40.

20. Ito K, Barnes PJ. COPD as a disease of accelerated lung aging. CHEST J. 2009;135:173-180.

21. Eng A, T'Mannetje A, Cheng S, et al. The New Zealand Workforce Survey I: self-reported occupational exposures. Ann Occup Hyg. 2010;54:144-153.

22. Moscato G, Galdi E. Asthma and hairdressers. Curr Opin Allergy Clin Immunol. 2006;6:91-95.

23. Slater T, Bradshaw L, Fishwick D, et al. Occupational respiratory symptoms in New Zealand hairdressers. Occup Med. 2000;50:586-590.

24. Medina-Ramon M, Zock JP, Kogevinas M, et al. Asthma, chronic bronchitis, and exposure to irritant agents in occupational domestic cleaning: a nested case-control study. Occup Environ Med. 2005;62:598-606.

25. Lillienberg L, Zock JP, Kromhout $\mathrm{H}$, et al. A population-based study on welding exposures at work and respiratory symptoms. Ann Occup Hyg. 2008;52:107-115.

26. Bradshaw LM, Fishwick D, Slater T, Pearce N. Chronic bronchitis, work related respiratory symptoms, and pulmonary function in welders in New Zealand. Occup Environ Med. 1998;55:150-154.

27. Fishwick D, Bradshaw L, Slater T, Curran A, Pearce N. Respiratory symptoms and lung function change in welders: are they associated with workplace exposures? N Z Med J. 2004;117:U872.

28. Kimbell-Dunn MR, Fishwick RD, Bradshaw L, Erkinjuntti-Pekkanen R, Pearce N. Workrelated respiratory symptoms in New Zealand farmers. Am J Ind Med. 2001;39:292-300.

29. Ghosh RE, Cullinan P, Fishwick D, et al. Asthma and occupation in the 1958 birth cohort. Thorax. 2013;68:365-371.

30. Shirtcliffe P, Marsh S, Travers J, Weatherall M, Beasley R. Childhood asthma and GOLD-defined chronic obstructive pulmonary disease. Int Med J. 2012;42:83-88.

31. Travers J, Marsh S, Williams M, et al. External validity of randomised controlled trials in asthma: to whom do the results of the trials apply? Thorax. 2007;62:219-223.

32. Eisner MD, Anthonisen N, Coultas D, et al. An official American Thoracic Society public policy statement: novel risk factors and the global burden of chronic obstructive pulmonary disease. Am J Respir Crit Care Med. 2010;182:693-718.

33. de Vocht F, Zock JP, Kromhout H, et al. Comparison of self-reported occupational exposure with a job exposure matrix in an international community-based study on asthma. Am J Ind Med. 2005;47:434-442.

34. Lai CKW, Beasley R, Crane J, et al. Global variation in the prevalence and severity of asthma symptoms: Phase Three of the International Study of Asthma and Allergies in Childhood (ISAAC). Thorax. 2009;64:476-483.

35. Le Moual N, Kauffmann F, Eisen EA, Kennedy SM. The healthy worker effect in asthma: work may cause asthma, but asthma may also influence work. Am J Respir Crit Care Med. 2008;177:4-10.

36. Mehta AJ, Miedinger D, Keidel D, et al. Occupational exposure to dusts, gases, and fumes and incidence of chronic obstructive pulmonary disease in the Swiss cohort study on air pollution and lung and heart diseases in adults. Am J Respir Crit Care Med. 2012;185:1292-1300.

37. Sunyer J, Zock JP, Kromhout $\mathrm{H}$, et al. Lung function decline, chronic bronchitis, and occupational exposures in young adults. Am J Respir Crit Care Med. 2005;172:1139-1145.

38. Matheson MC, Benke G, Raven J, et al. Biological dust exposure in the workplace is a risk factor for chronic obstructive pulmonary disease. Thorax. 2005;60:645-651.

39. Siebert U, Rothenbacher D, Daniel U, Brenner H. Demonstration of the healthy worker survivor effect in a cohort of workers in the construction industry. Occ Environ Med. 2001;58:774-779. 
Hansell, A., Ghosh, R.E., Poole, S., Zock, J.P., Weatherall, M., Vermeulen, R., Kromhout, H., Travers, J., Beasley, R. Occupational risk factors for chronic respiratory disease in a New Zealand population using lifetime occupational history. Journal of Occupational and Environmental Medicine: 2014, 56(3), 270-280

40. Li CY, Sung FC. A review of the healthy worker effect in occupational epidemiology. Occup Med. 1999;49:225-229.

41. Darby AC, Waterhouse JC, Stevens V, et al. Chronic obstructive pulmonary disease among residents of an historically industrialised area. Thorax. 2012;67:901-907.

42. Bellia V, Battaglia S, Catalano F, et al. Aging and disability affect misdiagnosis of COPD in elderly asthmatics: the Sara study. CHEST J. 2003;123:1066-1072.

43. Mannetje A, Kromhout $H$. The use of occupation and industry classifications in general population studies. Int J Epidemiol. 2003;32:419-428.

44. Vestbo J. Chronic bronchitis: should it worry us? Chron Respir Dis. 2004;1:173-176.

45. Voll-Aanerud M, Eagan T, Plana E, et al. Respiratory symptoms in adults are related to impaired quality of life, regardless of asthma and COPD: results from the European community respiratory health survey. Health Qual Life Out. 2010;8:107

\section{TABLES}

\begin{tabular}{|c|c|c|c|}
\hline & Both Sexes, $n(\%)$ & Male, $n(\%)$ & Female, $n(\%)$ \\
\hline \multicolumn{4}{|l|}{ Outcomes } \\
\hline Doctor diagnosis of COPD, emphysema, or chronic bronchitis & $112(11.0)$ & $45(8.8)$ & $67(13.3)$ \\
\hline Chronic bronchitis symptoms (cough AND sputum at least 3 mo of year) & $87(8.6)$ & $48(9.3)$ & $39(7.8)$ \\
\hline COPD LLN (FEV $1 / F V C$ below lower limit of normal) & $83(11.1)$ & $55(13.6)$ & $28(8.1)$ \\
\hline Asthma ever diagnosed & $243(23.9)$ & $112(21.8)$ & $131(26.0)$ \\
\hline First asthma diagnosis at or below the age of $16 \mathrm{yrs}$ & $98(39.7)$ & $56(49.6)$ & $42(31.3)$ \\
\hline \multicolumn{4}{|l|}{ Demographic } \\
\hline All with questionnaire data & $1017(100)$ & $514(50.5)$ & $503(49.5)$ \\
\hline All with questionnaire and spirometry data & $750(100)$ & $406(54.1)$ & $344(45.9)$ \\
\hline \multicolumn{4}{|l|}{ Age } \\
\hline $25-34$ yrs & $103(10.1)$ & $42(8.1)$ & $61(12.3)$ \\
\hline $35-44$ yrs & $173(17.0)$ & $77(15.0)$ & $96(19.1)$ \\
\hline $45-54$ yrs & $238(23.4)$ & $111(21.6)$ & $127(25.2)$ \\
\hline $55-64$ yrs & $261(25.7)$ & $150(29.2)$ & $111(22.1)$ \\
\hline $65-75 \mathrm{yrs}$ & $242(23.8)$ & $134(26.1)$ & $108(21.5)$ \\
\hline Ethnicity New Zealand Caucasian & $871(85.6)$ & $440(85.6)$ & $431(85.6)$ \\
\hline Ethnicity Maori or Pacific islander & $35(3.4)$ & $15(2.9)$ & $20(4.0)$ \\
\hline Ethnicity other and mixed & $111(10.9)$ & $59(11.5)$ & $52(10.3)$ \\
\hline Deprivation: top $10 \%$ of NZDep2001* & $315(31.0)$ & $167(32.6)$ & $148(29.5)$ \\
\hline Deprivation: bottom $50 \%$ of NZDep2001* & $246(24.2)$ & $111(21.6)$ & $135(26.9)$ \\
\hline Current smoker & $100(9.8)$ & $49(9.5)$ & $51(10.1)$ \\
\hline \multirow[t]{2}{*}{ Ex-smoker } & $385(37.9)$ & $203(39.5)$ & $182(36.2)$ \\
\hline & Mean (SD) & Mean (SD) & Mean (SD) \\
\hline Pack_years smoking & $7.5(14.48)$ & $9.1(17.08)$ & $5.8(11.0)$ \\
\hline Age, yrs & $53.2(12.87)$ & $54.7(12.56)$ & $51.7(13.02)$ \\
\hline Postbronchodilator $\mathrm{FEV}_{1}(\mathrm{~L}) \dagger$ & $3.33(0.970)$ & $3.71(0.99)$ & $2.87(0.71)$ \\
\hline Predicted $\mathrm{FEV}_{1} \%$ based on US NHANES equation & $103.2(18.2)$ & $102.2(19.1)$ & $104.4(17.1)$ \\
\hline $\mathrm{FEV}_{1}$ as $\%$ of predicted & $111.05(19.75)$ & $108.03(20.22)$ & $114.62(18.59)$ \\
\hline
\end{tabular}


Hansell, A., Ghosh, R.E., Poole, S., Zock, J.P., Weatherall, M., Vermeulen, R., Kromhout, H., Travers, J., Beasley, R. Occupational risk factors for chronic respiratory disease in a New Zealand population using lifetime occupational history. Journal of Occupational and Environmental Medicine: 2014, 56(3), 270-280

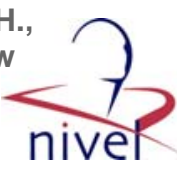

TABLE 2. Description of Data Set-Occupational Exposures

\begin{tabular}{|c|c|c|c|c|}
\hline & Both Sexes, $n(\%)$ & Male, $n(\%)$ & Female, $n(\%)$ & \\
\hline \multicolumn{5}{|l|}{ Self-reported exposures } \\
\hline Never any self-reported exposure (reference group) & $448(44.1)$ & $148(28.8)$ & $300(59.6)$ & \\
\hline \multicolumn{5}{|l|}{ Ever exposed to: } \\
\hline Solvents & $298(29.3)$ & $207(40.3)$ & $91(18.1)$ & \\
\hline Wood dust & $199(19.6)$ & $162(31.5)$ & $37(7.4)$ & \\
\hline Detergents & $191(18.8)$ & $109(21.2)$ & $82(16.3)$ & \\
\hline Petrol & $161(15.8)$ & $130(25.3)$ & $31(6.2)$ & \\
\hline Soldering & $153(15.0)$ & $138(26.9)$ & $15(3.0)$ & \\
\hline Welding & $126(12.4)$ & $119(23.2)$ & $7(1.4)$ & \\
\hline Asbestos & $109(10.7)$ & $102(19.8)$ & $7(1.4)$ & \\
\hline Pigments & $104(10.2)$ & $63(12.3)$ & $41(8.2)$ & \\
\hline Anhydrides (epoxy, vinyl, polyester, alkyd-resins) & $97(9.5)$ & $70(13.6)$ & $27(5.4)$ & \\
\hline Insecticides/pesticides & $89(8.8)$ & $60(11.7)$ & $29(5.8)$ & \\
\hline Aldehydes (formaldehyde, formalin) & $79(7.8)$ & $43(8.4)$ & $36(7.2)$ & \\
\hline Stone dust with quartz & $58(5.7)$ & $47(9.1)$ & $11(2.2)$ & \\
\hline Metal compounds in dust/gas form (chromium, nickel, platinum, zinc) & $53(5.2)$ & $43(8.4)$ & $10(2.0)$ & \\
\hline Aluminum dust & $40(3.9)$ & $35(6.8)$ & $5(1.0)$ & \\
\hline Plastic manufacture & $31(3.1)$ & $25(4.9)$ & $6(1.2)$ & \\
\hline Paint/lacquer manufacture & $27(2.7)$ & $21(4.1)$ & $6(1.2)$ & \\
\hline Diisocyanates (MDI, TDI, HDI, NDI) & $20(2.0)$ & $13(2.5)$ & $7(1.4)$ & \\
\hline Hairdressing & $19(1.9)$ & $2(0.4)$ & $17(3.4)$ & \\
\hline ALOHA JEM-based exposures & $\begin{array}{l}\text { Biological } \\
\text { Dust, } n(\%)\end{array}$ & $\begin{array}{c}\text { Mineral } \\
\text { Dust, } n(\%)\end{array}$ & $\begin{array}{c}\text { Gas/Fumes, } \\
n(\%)\end{array}$ & $\begin{array}{l}\text { VGDF, } \\
n(\%)\end{array}$ \\
\hline \multicolumn{5}{|l|}{ Both $(n=1014)$} \\
\hline Never any exposure & $610(60.2)$ & $719(70.9)$ & $510(50.3)$ & $452(44.6)$ \\
\hline Only ever low exposure & $276(27.2)$ & $160(15.8)$ & $351(34.6)$ & $327(32.3)$ \\
\hline Ever high exposure & $128(12.6)$ & $135(13.3)$ & $153(15.1)$ & $235(23.2)$ \\
\hline Cumulative exposure years among those with any exposure, median (IQR) & $14(4-34)$ & $15(4-37)$ & $14(4-36)$ & $19(4.5-46)$ \\
\hline \multicolumn{5}{|l|}{ Male $n=512$} \\
\hline Never any exposure & $305(59.6)$ & $289(56.5)$ & $218(42.6)$ & $197(38.5)$ \\
\hline Only ever low exposure & $106(20.7)$ & $112(21.9)$ & $184(35.9)$ & $131(25.6)$ \\
\hline Ever high exposure & $101(19.7)$ & $111(21.7)$ & $110(21.5)$ & $184(35.9)$ \\
\hline Cumulative exposure years among those with any exposure, median (IQR) & $19(5-46)$ & $20(6-40)$ & $19(5-44)$ & $32(7-76.5)$ \\
\hline \multicolumn{5}{|l|}{ Female $n=502$} \\
\hline Never any exposure & $305(60.8)$ & $430(85.7)$ & $292(58.2)$ & $255(50.8)$ \\
\hline Only ever low exposure & $170(33.9)$ & $48(9.6)$ & $167(33.3)$ & $196(39.0)$ \\
\hline Ever high exposure & $27(5.4)$ & $24(4.8)$ & $43(8.6)$ & $51(10.2)$ \\
\hline Cumulative exposure years-among those with any exposure- Median (IQR) & $9(3-25)$ & $5(3-11)$ & $9.5(3-26)$ & $11(3-27)$ \\
\hline
\end{tabular}

HDI, hexamethylene diisocyanate; IQR, interquartile range; JEM, job exposure matrix; MDI, methylene diphenyl diisocyanate; NDI, naphthalene diisocyanate; VGDF, vapors, gases, dusts, or fumes. 
Hansell, A., Ghosh, R.E., Poole, S., Zock, J.P., Weatherall, M., Vermeulen, R., Kromhout, H., Travers, J., Beasley, R. Occupational risk factors for chronic respiratory disease in a New Zealand population using lifetime occupational history. Journal of Occupational and Environmental Medicine: 2014, 56(3), 270-280

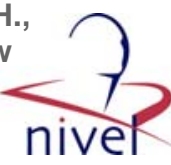

TABLE 3. ORs/Co-efs, ${ }^{*} 95 \% \mathrm{Cl}$ for Associations Between Cumulative Exposure (years) as Defined by the ALOHA JEM and Respiratory Outcomes

\begin{tabular}{|c|c|c|c|c|c|}
\hline \multirow{2}{*}{$\begin{array}{l}\text { ALOHA JEM Cumulative } \\
\text { Exposure (yrs) }\end{array}$} & \multirow[b]{2}{*}{$n /$ total } & \multicolumn{2}{|c|}{ Unadjusted } & \multicolumn{2}{|c|}{$\begin{array}{c}\text { Adjusted for Sex, Age, Age Squared, } \\
\text { Smoking (Pack Years), Ethnicity, } \\
\text { and Deprivation }\end{array}$} \\
\hline & & OR & $95 \% \mathrm{CI}$ & OR & $95 \% \mathrm{CI}$ \\
\hline \multicolumn{6}{|l|}{ COPD LLN $(n=750)$} \\
\hline Never exposure to any VGDF & $28 / 329$ & 1.00 & $\ldots$ & 1.00 & $\ldots$ \\
\hline Biological dust $>0-6$ & $7 / 97$ & 0.84 & $0.35-1.98$ & 0.54 & $0.20-1.44$ \\
\hline Biological dust 7-26 & $11 / 86$ & 1.58 & $0.75-3.31$ & 1.26 & $0.56-2.82$ \\
\hline Biological dust $27-228$ & $16 / 97$ & 2.12 & $1.10-4.11$ & 0.93 & $0.43-2.04$ \\
\hline Mineral dust $>0-6$ & $12 / 72$ & 2.15 & 1.044 .47 & 1.49 & $0.65-3.38$ \\
\hline Mineral dust 7-29 & $11 / 73$ & 1.91 & $0.90-4.03$ & 0.98 & $0.39-2.45$ \\
\hline Mineral dust 29.5-188 & $11 / 66$ & 2.15 & $1.01-4.57$ & 1.11 & $0.46-2.65$ \\
\hline Gases or fumes $>0-6$ & $11 / 131$ & 0.99 & $0.48-2.04$ & 0.84 & $0.39-1.83$ \\
\hline Gases or fumes $6.5-28$ & $17 / 121$ & 1.76 & $0.92-3.34$ & 1.23 & $0.60-2.50$ \\
\hline Gases or fumes $28.5-192$ & $18 / 114$ & 2.02 & $1.07-3.80$ & 0.90 & $0.43-1.88$ \\
\hline Any (VGDF) $>0-8$ & $16 / 147$ & 1.31 & $0.69-2.51$ & 1.18 & $0.59-2.37$ \\
\hline Any (VGDF) 9-35 & $13 / 129$ & 1.20 & $0.60-2.41$ & 0.92 & $0.43-1.95$ \\
\hline Any (VGDF) 36-240 & $24 / 133$ & 2.37 & $1.32-4.26$ & 1.02 & $0.51-2.03$ \\
\hline \multicolumn{6}{|c|}{ Doctor diagnosed COPD $(n=1017)$} \\
\hline Never exposure to any VGDF & $51 / 452$ & 1.00 & $\ldots$ & 1.00 & $\ldots$ \\
\hline Biological dust $>0-6$ & $15 / 140$ & 0.94 & $0.51-1.74$ & 0.81 & $0.43-1.52$ \\
\hline Biological dust 7-26 & $16 / 122$ & 1.19 & $0.65-2.16$ & 1.04 & $0.56-1.96$ \\
\hline Biological dust 27-228 & $10 / 130$ & 0.66 & $0.32-1.33$ & 0.64 & $0.30-1.35$ \\
\hline Mineral dust $>0-6$ & 9/96 & 0.81 & $0.39-1.71$ & 0.82 & $0.38-1.79$ \\
\hline Mineral dust 7-29 & $14 / 98$ & 1.31 & $0.69-2.48$ & 1.54 & $0.74-3.19$ \\
\hline Mineral dust 29.5-188 & $7 / 93$ & 0.64 & $0.28-1.46$ & 0.75 & $0.30-1.84$ \\
\hline Gases or fumes $>0-6$ & $19 / 169$ & 1.00 & $0.57-1.74$ & 0.98 & $0.55-1.73$ \\
\hline Gases or fumes $6.5-28$ & $20 / 164$ & 1.09 & $0.63-1.89$ & 1.06 & $0.60-1.89$ \\
\hline Gases or fumes $28.5-192$ & $10 / 158$ & 0.53 & $0.26-1.07$ & 0.47 & $0.22-1.01$ \\
\hline Any $($ VGDF) $>0-8$ & $22 / 195$ & 1.00 & $0.59-1.70$ & 0.97 & $0.56-1.67$ \\
\hline Any (VGDF) 9-35 & $21 / 174$ & 1.08 & $0.63-1.85$ & 1.01 & $0.58-1.77$ \\
\hline Any (VGDF) 36-240 & $14 / 179$ & 0.67 & $0.36-1.24$ & 0.58 & $0.29-1.14$ \\
\hline \multicolumn{6}{|c|}{ Chronic bronchitis symptoms ( $n=1017)$} \\
\hline Never exposure to any VGDF & $27 / 452$ & 1.00 & $\ldots$ & 1.00 & $\ldots$ \\
\hline Biological dust $>0-6$ & $14 / 140$ & 1.75 & $0.89-3.44$ & 1.31 & $0.63-2.69$ \\
\hline Biological dust 7-26 & $13 / 122$ & 1.88 & $0.94-3.76$ & 1.41 & $0.67-2.93$ \\
\hline Biological dust 27-228 & $16 / 130$ & 2.21 & $1.15-4.24$ & 1.34 & $0.65-2.76$ \\
\hline Mineral dust $>0-6$ & $13 / 96$ & 2.47 & $1.22-4.98$ & 2.07 & $0.98-4.35$ \\
\hline Mineral dust 7-29 & $12 / 98$ & 2.20 & $1.07-4.51$ & 1.42 & $0.61-3.27$ \\
\hline Mineral dust 29.5-188 & $14 / 93$ & 2.79 & $1.40-5.55$ & 1.87 & 0.844 .20 \\
\hline Gases or fumes $>0-6$ & $12 / 169$ & 1.20 & $0.59-2.43$ & 1.09 & $0.53-2.25$ \\
\hline Gases or fumes $6.5-28$ & $16 / 164$ & 1.70 & $0.89-3.25$ & 1.34 & $0.68-2.65$ \\
\hline Gases or fumes $28.5-192$ & $24 / 158$ & 2.82 & $1.57-5.05$ & 1.78 & $0.92-3.44$ \\
\hline Any (VGDF) $>0-8$ & $14 / 195$ & 1.22 & $0.62-2.38$ & 1.15 & $0.58-2.30$ \\
\hline Any (VGDF) 9-35 & $16 / 174$ & 1.59 & $0.84-3.04$ & 1.27 & $0.64-2.50$ \\
\hline \multirow[t]{2}{*}{ Any (VGDF) 36-240 } & $25 / 179$ & 2.56 & $1.44-4.54$ & 1.56 & $0.81-3.03$ \\
\hline & & Adju & and Height) & \multicolumn{2}{|c|}{$\begin{array}{l}\text { Adjusted for Sex, Age, Height, } \\
\text { Smoking (Pack Years) Ethnicity, } \\
\text { and Deprivation }\end{array}$} \\
\hline \multicolumn{6}{|c|}{ Predicted FEV $_{1}$ from NHANES III equation $(n=750)$} \\
\hline Biological dust $>0-6$ & 97 & 2.13 & -1.89 to 6.15 & 3.84 & -0.10 to 7.78 \\
\hline Biological dust 7-26 & 86 & 2.30 & -1.91 to 6.52 & 4.48 & $0.35-8.62$ \\
\hline Biological dust 27-228 & 97 & 0.65 & -3.55 to 4.84 & 3.99 & -0.17 to 8.15 \\
\hline Mineral dust $>0-6$ & 72 & -3.23 & -7.66 to 1.19 & -1.07 & -5.44 to 3.30 \\
\hline Mineral dust $7-29$ & 73 & -2.62 & -7.12 to 1.88 & 1.60 & -3.03 to 6.23 \\
\hline
\end{tabular}


Hansell, A., Ghosh, R.E., Poole, S., Zock, J.P., Weatherall, M., Vermeulen, R., Kromhout, H., Travers, J., Beasley, R. Occupational risk factors for chronic respiratory disease in a New Zealand population using lifetime occupational history. Journal of Occupational and Environmental Medicine: 2014, 56(3), 270-280

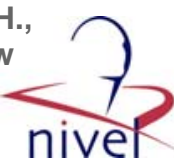

TABLE 3. (Continued)

\begin{tabular}{|c|c|c|c|c|c|}
\hline \multirow{2}{*}{$\begin{array}{l}\text { ALOHA JEM Cumulative } \\
\text { Exposure (yrs) }\end{array}$} & \multirow[b]{2}{*}{$n /$ total } & \multicolumn{2}{|c|}{ Adjusted (Age and Height) } & \multicolumn{2}{|c|}{$\begin{array}{l}\text { Adjusted for Sex, Age, Age Height, } \\
\text { Smoking (Pack Years), Ethnicity, } \\
\text { and Deprivation }\end{array}$} \\
\hline & & Co-ef & $95 \% \mathrm{Cl}$ & Co-ef & $95 \% \mathrm{Cl}$ \\
\hline Mineral dust 29.5-188 & 66 & 3.85 & -0.93 to 8.64 & 6.58 & $1.76-11.39 \dagger$ \\
\hline Gases or fumes $>0-6$ & 131 & 1.34 & -2.26 to 4.95 & 2.41 & -1.04 to 5.85 \\
\hline Gases or fumes $6.5-28$ & 121 & -1.65 & -5.35 to 2.06 & 1.02 & -2.59 to 4.63 \\
\hline Gases or fumes 28.5-192 & 114 & 2.03 & -1.86 to 5.93 & 6.29 & $2.41-10.16 \ddagger$ \\
\hline Any $(V G D F)>0-8$ & 147 & 0.17 & -3.34 to 3.68 & 1.08 & -2.33 to 4.49 \\
\hline Any (VGDF) 9-35 & 129 & 1.36 & -2.30 to 5.02 & 3.35 & -0.27 to 6.97 \\
\hline Any (VGDF) 36-240 & 133 & 0.22 & -3.57 to 4.00 & 4.04 & $0.21-7.87$ \\
\hline
\end{tabular}

All significant findings in the table are bold.

-Volume decrease/increase in postbronchodilator $\mathrm{FEV}_{1}$ with exposure.

†q-value significant $(0.042)$.

$\ddagger q$-value significant $(0.024)$, a $q$-value at or below 0.05 can be interpreted as meaning we can be $90 \%$ confident that the association is not due to chance. A $q$-value was calculated only when a statistically significant finding was present.

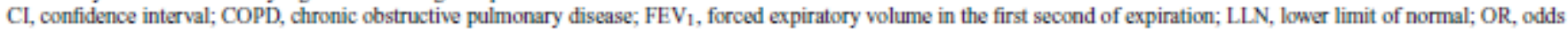
ratio; VGDF, vapors, gases, dusts, or fumes. 
Hansell, A., Ghosh, R.E., Poole, S., Zock, J.P., Weatherall, M., Vermeulen, R., Kromhout, H., Travers, J., Beasley, R. Occupational risk factors for chronic respiratory disease in a New Zealand population using lifetime occupational history. Journal of Occupational and Environmental Medicine: 2014, 56(3), 270-280

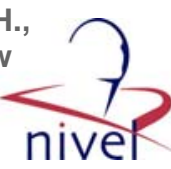

TABLE 4. ORs/Co-efs," $95 \% \mathrm{Cl}$ for Associations Between Self-reported Occupational Exposures and Respiratory Outcomes

\begin{tabular}{|c|c|c|c|c|c|}
\hline \multirow[b]{2}{*}{ Self-reported Exposures } & \multirow[b]{2}{*}{$n /$ total } & \multicolumn{2}{|c|}{ Unadjusted } & \multicolumn{2}{|c|}{$\begin{array}{c}\text { Adjusted for Sex, Age, Age Squared, } \\
\text { Smoking (Pack Years) Ethnicity, and } \\
\text { Deprivation }\end{array}$} \\
\hline & & OR & $95 \% \mathrm{CI}$ & OR & $95 \% \mathrm{CI}$ \\
\hline \multicolumn{6}{|l|}{$\operatorname{COPD} \operatorname{LLN}(n=750)$} \\
\hline No exposure & $33 / 320$ & 1.00 & $\ldots$ & 1.00 & $\ldots$ \\
\hline Petrol & $16 / 121$ & 1.33 & $0.7-2.51$ & 1.04 & $0.46-2.34$ \\
\hline Solvents & $25 / 229$ & 1.07 & $0.62-1.85$ & 0.72 & $0.38-1.38$ \\
\hline Detergents & $11 / 134$ & 0.78 & $0.38-1.59$ & 0.55 & $0.24-1.25$ \\
\hline Pigments & $8 / 75$ & 1.04 & $0.46-2.35$ & 0.66 & $0.25-1.73$ \\
\hline Plastic manufacturing & $3 / 18$ & $\ldots$ & $\ldots$ & $\ldots$ & $\ldots$ \\
\hline Paint manufacturing & $5 / 23$ & 2.42 & $0.84-6.93$ & 2.37 & $0.69-8.11$ \\
\hline Insecticides & $8 / 71$ & 1.10 & $0.49-2.51$ & 0.91 & $0.35-2.35$ \\
\hline Metal compounds & $4 / 40$ & $\ldots$ & $\ldots$ & $\ldots$ & $\ldots$ \\
\hline Diisocyanates & $2 / 12$ & $\ldots$ & $\ldots$ & $\ldots$ & $\ldots$ \\
\hline Aldehydes & $1 / 66$ & $\ldots$ & $\ldots$ & $\ldots$ & $\ldots$ \\
\hline Anhydride & $9 / 75$ & 1.19 & $0.54-2.6$ & 0.84 & $0.33-2.12$ \\
\hline Asbestos & $16 / 91$ & 1.86 & $0.97-3.55$ & 1.04 & $0.43-2.48$ \\
\hline Stone dust & $6 / 47$ & 1.27 & $0.5-3.22$ & 0.82 & $0.26-2.59$ \\
\hline Wood dust & $18 / 149$ & 1.20 & $0.65-2.2$ & 0.78 & $0.35-1.74$ \\
\hline Aluminum & $3 / 28$ & $\ldots$ & $\ldots$ & $\ldots$ & $\ldots$ \\
\hline Welding & $14 / 102$ & 1.38 & $0.71-2.7$ & 0.95 & $0.39-2.3$ \\
\hline Soldering & $14 / 118$ & 1.17 & $0.6-2.27$ & 0.84 & $0.36-1.92$ \\
\hline Hairdressing & $a / 13$ & $\ldots$ & $\ldots$ & $\ldots$ & $\ldots$ \\
\hline \multicolumn{6}{|c|}{ Doctor diagnosed COPD $(n=1017)$} \\
\hline No exposure & $52 / 448$ & 1.00 & $\ldots$ & 1.00 & $\ldots$ \\
\hline Petrol & $10 / 161$ & 0.50 & $0.25-1.02$ & 0.48 & $0.22-1.06$ \\
\hline Solvents & $25 / 298$ & 0.70 & $0.42-1.15$ & 0.76 & $0.43-1.34$ \\
\hline Detergents & $21 / 191$ & 0.94 & $0.55-1.61$ & 0.99 & $0.55-1.80$ \\
\hline Pigments & $7 / 104$ & 0.55 & $0.24-1.25$ & 0.50 & $0.21-1.22$ \\
\hline Plastic manufacturing & $6 / 31$ & 1.83 & $0.72-4.66$ & 1.38 & $0.46-4.10$ \\
\hline Paint manufacturing & $4 / 27$ & $\ldots$ & $\ldots$ & $\ldots$ & $\ldots$ \\
\hline Insecticides & $7 / 89$ & 0.65 & $0.29-1.48$ & 0.69 & $0.29-1.68$ \\
\hline Metal compounds & $7 / 53$ & 1.16 & $0.50-2.70$ & 1.07 & $0.41-2.75$ \\
\hline Diisocyanates & $2 / 20$ & $\ldots$ & $\ldots$ & $\ldots$ & $\ldots$ \\
\hline Aldehydes & $7 / 79$ & 0.74 & $0.32-1.69$ & 0.72 & $0.31-1.70$ \\
\hline Anhydride & $8 / 97$ & 0.68 & $0.31-1.49$ & 0.68 & $0.29-1.59$ \\
\hline Asbestos & $12 / 109$ & 0.94 & $0.48-1.83$ & 0.94 & $0.41-2.12$ \\
\hline Stone dust and quartz & $4 / 58$ & $\ldots$ & $\ldots$ & $\ldots$ & $\ldots$ \\
\hline Wood dust & $17 / 199$ & 0.71 & $0.40-1.26$ & 0.78 & $0.40-1.53$ \\
\hline Aluminum dust & $3 / 40$ & $\ldots$ & $\ldots$ & $\ldots$ & $\ldots$ \\
\hline Welding & $12 / 126$ & 0.80 & $0.41-1.55$ & 0.98 & $0.44-2.19$ \\
\hline Soldering & $11 / 153$ & 0.59 & $0.30-1.16$ & 0.65 & $0.29-1.46$ \\
\hline Hairdressing & $4 / 19$ & $\ldots$ & $\ldots$ & $\ldots$ & $\ldots$ \\
\hline \multicolumn{6}{|c|}{ Chronic bronchitis symptoms $(n=1017)$} \\
\hline No exposure & $27 / 448$ & 1.00 & $\ldots$ & 1.00 & $\ldots$ \\
\hline Petrol & $20 / 161$ & 2.21 & $1.20-4.07$ & 1.54 & $0.75-3.17$ \\
\hline Solvents & $28 / 298$ & 1.62 & $0.93-2.80$ & 1.15 & $0.61-2.15$ \\
\hline Detergents & $26 / 191$ & 2.46 & $1.39-4.34$ & 2.16 & $1.13-4.09$ \\
\hline Pigments & $14 / 104$ & 2.43 & $1.22-4.81$ & 1.73 & $0.79-3.81$ \\
\hline Plastic manufacturing & $6 / 31$ & 3.74 & $1.42-9.89$ & 2.75 & $0.82-9.19$ \\
\hline Paint manufacturing & $6 / 27$ & 4.46 & $1.66-11.96$ & 3.46 & $1.09-11.05$ \\
\hline Insecticides & $13 / 89$ & 2.67 & $1.32-5.40$ & 2.35 & $1.05-5.26$ \\
\hline Metal compounds & $5 / 53$ & 1.62 & $0.60-4.41$ & 1.12 & $\begin{array}{l}0.34-3.68 \\
\text { (Continues) }\end{array}$ \\
\hline
\end{tabular}


Hansell, A., Ghosh, R.E., Poole, S., Zock, J.P., Weatherall, M., Vermeulen, R., Kromhout, H., Travers, J., Beasley, R. Occupational risk factors for chronic respiratory disease in a New Zealand population using lifetime occupational history. Journal of Occupational and Environmental Medicine: 2014, 56(3), 270-280

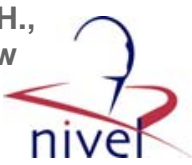

TABLE 4. (Continued)

\begin{tabular}{|c|c|c|c|c|c|}
\hline \multirow[b]{2}{*}{ Self-reported Exposures } & \multirow[b]{2}{*}{$n /$ total } & \multicolumn{2}{|c|}{ Unadjusted } & \multicolumn{2}{|c|}{$\begin{array}{c}\text { Adjusted for Sex, Age, Age Squared, } \\
\text { Smoking (Pack Years) Ethnicity, and } \\
\text { Deprivation }\end{array}$} \\
\hline & & OR & $95 \% \mathrm{Cl}$ & OR & $95 \% \mathrm{CI}$ \\
\hline Diisocyanates & $2 / 20$ & $\cdots$ & $\cdots$ & $\cdots$ & $\ldots$ \\
\hline Aldehydes & $7 / 79$ & 1.52 & $0.64-3.61$ & 1.28 & $0.51-3.25$ \\
\hline Anhydride & $11 / 97$ & 1.99 & $0.95-4.17$ & 1.72 & $0.73-4.05$ \\
\hline Asbestos & $10 / 109$ & 1.58 & $0.74-3.36$ & 0.98 & $0.38-2.52$ \\
\hline Stone dust & $7 / 58$ & 2.14 & $0.89-5.16$ & 1.80 & $0.65-5.02$ \\
\hline Wood dust & $17 / 199$ & 1.46 & $0.77-2.74$ & 1.09 & $0.50-2.36$ \\
\hline Aluminum & $5 / 40$ & 2.23 & $0.81-6.14$ & 1.52 & $0.47-4.89$ \\
\hline Welding & $21 / 126$ & 3.12 & $1.70-5.73$ & 2.27 & $1.02-5.08$ \\
\hline Soldering & $15 / 153$ & 1.69 & $0.88-3.28$ & 1.17 & $0.51-2.67$ \\
\hline \multirow[t]{2}{*}{ Hairdressing } & $5 / 19$ & 5.57 & $1.87-16.61$ & 6.91 & $2.02-23.70 \dagger$ \\
\hline & & Adj & and Height) & \multicolumn{2}{|c|}{$\begin{array}{l}\text { Adjusted for Sex, Age, Height, } \\
\text { Smoking (Pack Years) Ethnicity, } \\
\text { and Deprivation }\end{array}$} \\
\hline \multicolumn{6}{|c|}{ Predicted FEV ${ }_{1} \%$ from NHANES III equation $(n=750)$} \\
\hline Petrol & 121 & -3.22 & -7.24 to 0.79 & -0.86 & -5.00 to 3.29 \\
\hline Solvents & 229 & 1.40 & -1.72 to 4.53 & 3.99 & $0.83-7.15$ \\
\hline Detergents & 134 & 0.85 & -2.71 to 4.41 & 3.89 & $0.22-7.55$ \\
\hline Pigments & 75 & 0.48 & -4.19 to 5.14 & 2.71 & -2.04 to 7.47 \\
\hline Plastic manufacturing & 18 & -8.79 & -17.43 to -0.15 & -6.54 & -15.49 to 2.4 \\
\hline Paint manufacturing & 23 & -2.48 & -9.96 to 5.00 & -1.83 & -9.66 to 6.00 \\
\hline Insecticides & 71 & -1.40 & -6.03 to 3.23 & -0.66 & -5.39 to 4.08 \\
\hline Metal compounds & 40 & 4.19 & -1.77 to 10.16 & 4.75 & -1.45 to 10.95 \\
\hline Diisocyanates & 12 & -0.53 & -10.67 to 9.62 & -0.65 & -11.17 to 9.86 \\
\hline Aldehydes & 66 & 4.23 & -0.29 to 8.75 & 4.42 & -0.13 to 8.98 \\
\hline Anhydride & 75 & 0.03 & -4.66 to 4.72 & 1.18 & -3.55 to 5.91 \\
\hline Asbestos & 91 & 2.75 & -1.76 to 7.26 & 5.39 & 0.54 to 10.25 \\
\hline Stone dust & 47 & -0.12 & -5.71 to 5.46 & 1.36 & -4.39 to 7.11 \\
\hline Wood dust & 149 & 1.36 & -2.24 to 4.95 & 3.45 & -0.36 to 7.26 \\
\hline Aluminum & 28 & -2.68 & -9.64 to 4.28 & -0.78 & -7.9 to 6.33 \\
\hline Welding & 102 & -0.09 & -4.45 to 4.26 & 3.36 & -1.31 to 8.03 \\
\hline Soldering & 118 & -0.89 & -4.96 to 3.18 & 1.97 & -2.37 to 6.30 \\
\hline Hairdressing & 13 & 3.09 & -6.53 to 12.71 & 3.63 & -6.09 to 13.34 \\
\hline
\end{tabular}

*Volume decrease/increase in postbronchodilator $\mathrm{FEV}_{1}$ with exposure.

$† Q$-value significant ( 0.034$)$, a $q$-value at or below 0.05 can be interpreted as meaning we can be $90 \%$ confident that the association is not due to chance. A $q$-value was calculated only when a statistically significant finding was present. ratio.

$\mathrm{Cl}$, confidence interval; COPD, chronic obstructive pulmonary disease; $\mathrm{FEV}_{1}$, forced expiratory volume in the first second of expiration; LLN, lower limit of normal; OR, odds 
Hansell, A., Ghosh, R.E., Poole, S., Zock, J.P., Weatherall, M., Vermeulen, R., Kromhout, H., Travers, J., Beasley, R. Occupational risk factors for chronic respiratory disease in a New Zealand population using lifetime occupational history. Journal of Occupational and Environmental Medicine: 2014, 56(3), 270-280

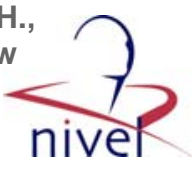

TABLE 5. ORs/Co-efs, ${ }^{*} 95 \% \mathrm{Cl}$ for Associations Between Ever Exposure as Defined by the ALOHA JEM and Respiratory Outcomes

\begin{tabular}{|c|c|c|c|c|c|}
\hline \multirow[b]{2}{*}{ ALOHA JEM Exposure } & \multirow[b]{2}{*}{$n /$ total } & \multicolumn{2}{|c|}{ Unadjusted } & \multicolumn{2}{|c|}{$\begin{array}{c}\text { Adjusted for Sex, Age, Age Squared, } \\
\text { Smoking (Pack Years) Ethnicity, and } \\
\text { Deprivation }\end{array}$} \\
\hline & & OR & $95 \% \mathrm{CI}$ & OR & $95 \% \mathrm{CI}$ \\
\hline \multicolumn{6}{|l|}{ COPD LLN $(n=750)$} \\
\hline No exposure & $28 / 329$ & 1.00 & $\ldots$ & 1.00 & $\ldots$ \\
\hline Biological dust —only low & $21 / 194$ & 1.30 & $0.72-2.37$ & 0.95 & $0.50-1.83$ \\
\hline Biological dust - ever high & $15 / 93$ & 2.07 & $1.05-4.06$ & 0.96 & $0.43-2.13$ \\
\hline Mineral dust - only low & $21 / 119$ & 2.30 & $1.25-4.24$ & 1.38 & $0.68-2.80$ \\
\hline Mineral dust - ever high & $14 / 97$ & 1.81 & $0.91-3.60$ & 0.96 & $0.43-2.16$ \\
\hline Gases or fumes only low & $33 / 269$ & 1.50 & $0.88-2.56$ & 1.01 & $0.56-1.81$ \\
\hline Gases or fumes - ever high & $14 / 106$ & 1.64 & $0.83-3.24$ & 0.85 & $0.39-1.85$ \\
\hline Any (VGDF) - only low & $29 / 246$ & 1.44 & $0.83-2.48$ & 1.19 & $0.67-2.12$ \\
\hline Any (VGDF)—ever high & $26 / 173$ & 1.90 & $1.08-3.36$ & 0.92 & $0.47-1.79$ \\
\hline \multicolumn{6}{|c|}{ Doctor diagnosed COPD $(n=1017)$} \\
\hline No exposure & $51 / 452$ & 1.00 & $\ldots$ & 1.00 & $\ldots$ \\
\hline Biological dust — only low & $34 / 276$ & 1.10 & $0.70-1.75$ & 0.95 & $0.58-1.54$ \\
\hline Biological dust - ever high & $9 / 128$ & 0.59 & $0.28-1.24$ & 0.56 & $0.25-1.23$ \\
\hline Mineral dust —only low & $17 / 160$ & 0.93 & $0.52-1.67$ & 0.97 & $0.51-1.84$ \\
\hline Mineral dust - ever high & $14 / 135$ & 0.91 & $0.49-1.70$ & 1.01 & $0.50-2.03$ \\
\hline Gases or fumes - only low & $37 / 351$ & 0.93 & $0.59-1.45$ & 0.91 & $0.58-1.45$ \\
\hline Gases or fumes ever high & $15 / 153$ & 0.85 & $0.47-1.57$ & 0.80 & $0.41-1.54$ \\
\hline Any (VGDF) - only low & $39 / 327$ & 1.06 & $0.68-1.66$ & 0.99 & $0.63-1.56$ \\
\hline Any (VGDF) - ever high & $21 / 235$ & 0.77 & $0.45-1.32$ & 0.71 & $0.39-1.28$ \\
\hline \multicolumn{6}{|c|}{ Chronic bronchitis symptoms ( $n=1017)$} \\
\hline No exposure & $27 / 452$ & 1.00 & $\ldots$ & 1.00 & $\ldots$ \\
\hline Biological dust — only low & $33 / 276$ & 2.14 & $1.26-3.64$ & 1.61 & $0.92-2.83$ \\
\hline Biological dust - ever high & $14 / 128$ & 1.93 & $0.98-3.81$ & 1.08 & $0.51-2.28$ \\
\hline Mineral dust - only low & $24 / 160$ & 2.78 & $1.55-4.97$ & 2.04 & $1.06-3.93$ \\
\hline Mineral dust - ever high & $19 / 135$ & 2.58 & $1.38-4.80$ & 1.87 & $0.91-3.80$ \\
\hline Gases or fumes - only low & $31 / 351$ & 1.52 & $0.89-2.61$ & 1.21 & $0.69-2.13$ \\
\hline Gases or fumes ever high & $25 / 153$ & 3.07 & $1.72-5.48$ & 2.10 & $1.11-3.98$ \\
\hline Any (VGDF) - only low & $27 / 327$ & 1.42 & $0.81-2.46$ & 1.27 & $0.72-2.25$ \\
\hline \multirow[t]{2}{*}{ Any (VGDF) - ever high } & $32 / 235$ & 2.48 & $1.45-4.25$ & 1.54 & $0.84-2.85$ \\
\hline & & \multicolumn{2}{|c|}{ Adjusted (Age and Height) } & \multicolumn{2}{|c|}{$\begin{array}{l}\text { Adjusted for Sex, Age, Height, Smoking } \\
\text { (Pack Years) Ethnicity, and Deprivation }\end{array}$} \\
\hline \multicolumn{6}{|c|}{ Predicted FEV 1 from NHANES III equation $(n=750)$} \\
\hline Biological dust—only low & 194 & 2.49 & -0.67 to 5.64 & 3.96 & $0.85-7.06 \dagger$ \\
\hline Biological dust - ever high & 93 & -0.56 & -4.72 to 3.6 & 3.54 & -0.70 to 7.78 \\
\hline Mineral dust - only low & 119 & -2.40 & -6.12 to 1.32 & 0.26 & -3.49 to 4.01 \\
\hline Mineral dust - ever high & 97 & 1.03 & -3.01 to 5.06 & 4.37 & $0.30-8.43$ \\
\hline Gases or fumes - only low & 269 & -0.01 & -2.87 to 2.86 & 1.89 & -0.88 to 4.66 \\
\hline Gases or fumes ever high & 106 & 1.87 & -2.04 to 5.78 & 5.83 & $1.94-9.71 \ddagger$ \\
\hline Any (VGDF) - only low & 246 & 0.39 & -2.58 to 3.36 & 1.22 & -1.67 to 4.11 \\
\hline Any (VGDF) — ever high & 173 & 0.48 & -2.90 to 3.85 & 4.38 & $0.92-7.83 \dagger$ \\
\hline \multicolumn{6}{|c|}{$\begin{array}{l}\text { All significant findings in the table are bold. } \\
\text { *Volume decrease/increase in postbronchodilator } \mathrm{FEV}_{1} \text { with exposure. } \\
\dagger q \text {-value significant }(0.035) \text {. } \\
\ddagger q \text {-value significant }(0.024) \text {, a } q \text {-value at or below } 0.05 \text { can be interpreted as meaning we can be } 90 \% \text { confident that the association is not due to chance. A } q \text {-value was } \\
\text { culated only when a statistically significant finding was present. } \\
\mathrm{Cl} \text {, confidence interval; COPD, chronic obstructive pulmonary disease; } \mathrm{FEV}_{1} \text {, forced expiratory volume in the first second of expiration; LLN, lower limit of normal; OR, odds } \\
\text { io; VGDF, vapors, gases, dusts, or fumes. }\end{array}$} \\
\hline
\end{tabular}

